Agrovoc descriptors: rural areas, cultivated land, landscape, public opinion, social values, cultural values, surveys, behaviour, cultural behaviour, regional planning, rural planning

Agris category code: P01, E11, E50

\title{
Scenario use for fostered adaptation to the future landscape changes ${ }^{1}$
}

\author{
Damjana GANTAR ${ }^{2}$
}

Received October 6, 2008; accepted April 2, 2009.

Delo je prispelo 6. oktobra 2008; sprejeto 2. aprila, 2009.

\begin{abstract}
Article presents the review of the theoretical framework for a specific question that arose from the use of the scenario technique in the field of landscape planning. This specific issue is: does the use of scenarios influence the perception of the cultural landscape changes and actions the individuals take to change the cultural landscape? Review includes research articles aiming to approve the influence of scenarios and also case studies of scenario use in the field of landscape planning that perceived possible influence of scenario use on stakeholders. The decision for the review was stimulated by the growing popularity of the scenario-based studies connected with landscape planning and environmental issues. Scenarios are also an important incentive for public participation. The question is whether we can influence relations between individuals and cultural landscape by showing them evidently with scenarios, how the future landscape will look like.
\end{abstract}

Keywords: land use scenarios, psychological aspects of scenario use, changes of perception and behaviour, cultural landscape changes

\section{IZVLEČEK}

\section{SCENARIJI RAZVOJA KULTURNE KRAJINE ZA LAŽJO PREDSTAVLJIVOST SPREMEMB V PROSTORU}

Pri vse pogostejši uporabi scenarijev na področju krajinskega in prostorskega planiranja se zastavlja vprašanje, kako scenariji razvoja kulturne krajine vplivajo na dojemanje sprememb kulturne krajine pri deležnikih ter s tem posredno tudi na njihovo delovanje $\mathrm{v}$ kulturni krajini. Članek podaja pregled nad posameznimi tujimi raziskavami, ki se vsebinsko navezujejo na vprašanje psihološkega vpliva scenarijev na deležnike, ter primeri uporabe scenarijev $\mathrm{v}$ načrtovalskih postopkih, kjer so raziskovalci zasledili relevanten vpliv te metode na deležnike. Uporaba scenarijev $\mathrm{v}$ postopkih sodelovanja $\mathrm{z}$ javnostjo je zaželena metoda za spodbujanje participacije javnosti, saj scenariji zaradi svoje privlačnosti nemalokrat olajšajo komunikacijo med raziskovalci in javnostjo. Pogosta uporaba scenarijev pri prostorskem planiranju in reševanju okoljskih vprašanj je spodbudila razmislek o tem, da uporaba scenarijev, za prikaz morebitnih prihodnjih sprememb kulturne krajine, vpliva na odnos deležnikov do kulturne krajine.

Ključne besede: scenariji razvoja kulturne krajine, psihološki vidiki uporabe scenarijev, vpliv na dojemanje sprememb, spremembe kulturne krajine

\footnotetext{
1 Prispevek je del doktorskega dela: Scenarij razvoja kulturne krajine kot dejavnik spreminjanja stališč in ravnanja deležnikov, mentorica: doc. dr. Mojca Golobič, univ. dipl. inž. kraj. arh.

Paper is a part of doctoral thesis: Scenarij razvoja kulturne krajine kot dejavnik spreminjanja stališč in ravnanja deležnikov, menthor: Assist. Prof, Ph.D. Mojca Golobič, Landscape Architect

2 Urbanistični inštitut Republike Slovenije, Trnovski pristan 2, 1127 Ljubljana, damjana.gantar@uirs.si
} 


\section{INTRODUCTION AND BACKGROUND OF THE REVIEW}

Scenarios enable identification and demonstration of the effects of different activities in the real space of the future, which can also influence the present and planned activities. By informing about undesired consequences, scenarios can help the actors (either individuals or institutions which perform the public policies) change their activities and adjust them so that they could avoid the negative effects and strengthen the positive effects on the landscape. Another important aspect of the scenario use is participation of decision makers and public in the decision making process. Scenarios are an easy to understand and convincing tool for presenting potential consequences of alternative decisions as well as for articulating and communicating attitudes and opinions. Use of the scenarios for the purpose of public informing and education proved to be a very helpful tool to promote understanding of the links between planned intervention and environment/space, land-use and changes in living conditions. Many cases showed (e. g. Wollenberg et al., 2000; Shearer, 2005; B. Tress and G. Tress, 2003) that use of the scenarios in participative process foster informed decisions and behaviour. Luke and Rutheford (1999, cited in: Public..., 2003) write about great significance of including the public and stimulation of their cooperation in solving global environmental issues, such as climate changes. Wollenberg et al. (2000) pointed out the influences of the scenarios on spatial planning and management. They found out that scenarios are not only useful for preparation of different measures in case of changes, but they also anticipate changes. Psychological influences of the scenarios on perceptions of the future were assessed by Gregory and Duran (2001) but the research wasn't focused on the use of the scenarios for representing changes of the cultural landscape or the space. The conclusion was that scenarios influence the awareness of different possibilities of the development and also change expectations in respect of probable events in the future.

\subsection{Origins and meaning of the scenarios}

Scenario-based research began in the middle of the $20^{\text {th }}$ century as an approach in decision-making among alternative futures and to help manage the inherent uncertainties. Applicability in spatial planning began to increase since the early 1970s (Shearer, 2005). The whole spectrum of the scenarios is very broad and they can be used for various purposes.

As alternative views of the future the scenarios can help to manage uncertainties of decisions based on assumptions instead of facts, which is an unavoidable consequence of investigating future. Use of the scenarios to preview potential consequences of different future contexts can help to improve decisions and to direct the development towards desired changes in space. Scenarios present abstract constructions of possible future developments and incorporate different future-oriented studies and techniques. Different aims of future studies and different approaches lead to variety of scenario definitions.

According to Shearer (2005), scenarios are fictional accounts, which represent a process of change over some duration; they describe situations, actions and consequences which are contingently related. The scenarios are understood to be predictive judgments, which describe what could happen, and not predictions which describe what will happen. Scenarios are constructed for the purpose of focusing attention on causal processes and decision points (Kahn and Wiener, 1967, cited in: Shearer, 2005). Another definition introduced by Shoemaker (cited in: Wollenberg et al., 2000) states that the scenarios stimulate creative ways of thinking, which help actors to upgrade the fixed ways of assessing the situation and planning of the activities. This enables them to adjust better to the future. Accordingly Armstrong (Principles..., 2001, p.16) warns that scenarios should not be used to make forecasts, because they could turn out wrong and convincing. Scenarios can lead people to take forecasts seriously. They create an increase in the perceived likelihood of the event and can motivate decision makers to think the situation trough.

\subsection{Background of the review}

The review focused on the literature that discusses psychological view of the scenario use. Only few articles (Gregory and Duran, 2001, Shearer, 2005, Aligica, 2005) were actually accordant with this subject, many more presented case studies on scenario use and under results or discussion also mention the noticed responses of public (Masini and Vasquez, 2000, Wollenberg et al., 2000, Santelmann, 2004). Nevertheless, this literature is very important, as it also presents the scenario use in fields of landscape or spatial planning. The majority of literature is more business/ economics oriented, mostly dealing with methodology and benefits of the scenario use in strategic planning of company operation (Lindgren and Bandhold, 2003). Also the contribution of futurists must not be neglected since it brings significant knowledge about theory of the scenario building and also of the ethics on the scenario use (Schwartz, 1991; Mannermaa, 1996).

The review shows, just as mentioned by Gregory and Duran (2001), that literature on scenarios mainly presents case studies, but fails to present the efficacy and/or the drawbacks of the scenario use and, in this specific case the facts that make scenarios a tool for 
influencing a person or a group of people. The word influencing, like manipulating, has positive and also a negative connotation. Influence (Wikipedia..., 2007) is a term that refers to ability to control or affect indirectly the actions of other people or things. Influence is when the actions or thoughts of individual(s) are changed by other individual(s).

The primary result of the review is the acquired knowledge about the influence of the scenarios on perceptions of the future and on activities or measures individuals take in the landscape. The review will elucidate possibilities of using the scenarios to increase the awareness and to stimulate desired activities in order to prevent negative consequences, or to stimulate positive consequences of the spatial development in the future.
1.3 Scenarios as a tool for research and a tool for planning

The largest share of reviewed articles presents psychological studies of the scenarios and case studies of the scenario use in landscape planning. The first type of literature presents scenarios as a tool for research. Where the results were obtained through guided and controlled experiments in order to prove psychological effects of the scenarios. The second type of the literature are case studies of planning processes that used scenarios as a planning tool to present future changes of landscape and environment. These scenarios are mainly aiming at exchanging the knowledge and the viewpoint of different stakeholders about the future development of landscape or the environment on general.

Both types of scenarios were equally important for the further research aiming at verifying the hypothesis that (land use) scenarios influence the perceptions about the future and activities connected with space and environment.

\section{FINDINGS AND DISCUSSION}

\subsection{Why do scenarios work?}

Lately scenarios are frequently mentioned and used in different fields and studies connected with investigating and planning the future, e.g. public policy, strategic thinking, management and planning, also including spatial and landscape planning as special fields. As a scientific tool the use of the scenarios can be questionable. The investigation of the future can not be grounded solely on provable facts, a certain part of it is inevitably speculative. The relevance of the scenarios as a kind of experiment is mostly being questioned in academic circles. According to Aligica (2005), the scenarios have the reputation of being "puzzling". Although the methodology, the toolbox and the forecasting practice are firmly established, the reluctance is presumably for their probable or possible character. Scenarios are cognitive constructs and as such they can and must be first explained from the psychological point of view, especially if we want to elucidate their influence on people's perceptions and actions.

Lindgren and Bandhold (2003, p. 29) suggest that scenarios are powerful as their narrative format (usually in the form of images and stories) is very memorable and enables us to develop an emotional relationship; by forcing the mind to think about qualitatively different directions, one improves the ability to foresee unusual events. Through scenarios complex situations can be reduced to a manageable amount of uncertainty and they are easy to communicate and to discuss. Different authors mention that the use of the scenarios is inherent to people. Thinking in scenarios helps us to understand the logic of developments, clarify driving forces, key factors, key players and our own potential to exert an influence. Scenarios may function both as an inspiration for generating idea and as filters trough which new ideas and projects can be passed. Scenarios may also be used for learning and to drive change. They are powerful in challenging existing paradigms and assumptions, especially for those who are involved in the scenario generation. Therefore scenario workshops are powerful instruments in the process of challenging existing paradigms and creating shared perspectives on the future.

Scenario building is therefore also an intuitive and creative process, but it must be based on thorough research of present and past conditions and future development and trends to ensure the validity of their use. Aligica (2005) questions the epistemic value and knowledge creation of scenarios, since they can not be subjected to empirical proofs and confirmed by "hard" evidence. Author also stresses that scenarios above all have cognitive nature, without it they would be just "pale psychological exercises meant to alleviate fear, to motivate and to please imagination and aesthetic urges about the future". He also cites Fauconnier and Turner that have characterized scenarios as a blend that can have effect in cognition, leading us to modify the initial inputs and to change our view of the corresponding situations. A blend is "a result of cognitive blending that consists of composition, completition and elaboration, and refers to the ability of the mind to take different 
concepts or mental constructs, form a cognitive link between them and produce a new concept or mental construct that is a blending of the first two or more" (Fauconnier and Turner, 2002, cited in: Aligica 2005).

The reviewed literature clearly attributes to the scenarios as a very helpful and suitable tool, what is also confirmed by frequent use of scenarios. The role of scenarios is quite heterogeneous, from dealing with uncertainties, forecasting, planning aid, educational means, to assessing the results of different measures and actions. Scenarios as a planning tool are powerful because they can clearly present the future situation in a narrative way, however sometimes this leads to oversimplification, but it is important as it enables the demonstration of complex environments or processes. Mostly the positive characteristics of scenario use prevail over negative. As negative, they have to be mentioned the credibility of the scenarios, doubtful scientific value and what is mostly important for the issue presented in this article, the ability to mislead and influence people if used inappropriate.

\subsection{Research of scenario influence}

Regardless of how scenarios are created and the purpose of their use they have been marked to have influence on people's expectation about the futures (Gregory and Duran 2001, Shearer 2005). Evidence suggests that the ease with which scenarios are imagined and constructed, or its plausibility, increases the belief that the depicted event could occur. Gregory and Duran (2001) composed a review of research aiming at verifying the influence of different scenarios on expectations and behaviour connected with events presented in scenarios. Main conclusions and issue related findings of resumed research are presented below.

Events that have not yet occurred, and unknown situations are sometimes hard to imagine, but the ability to imagine the future in all kinds of scenarios is very helpful. Tversky and Kahneman (1973) speculated that when a particular event has never occurred to us, or is infrequent, we may construct scenarios of the events occurrence. The ease we construct a scenario with its plausibility then infers the event's likelihood. This presumption was confirmed by Carroll (1979), who made two experiments with scenarios, one included election-outcome results, the other results of a football game. Carroll also established that scenarios may not work on everyone as a result of their previously held beliefs or their experiences. Gregory, Cialdini and Carpenter (1982) and later Gregory, Burroughs and Ainslie (1985) upgraded Carroll's work to self-relevant events that could happen to research participants, and were of a more personal nature (i.e. being arrested for armed robbery, winning a vacation trip, being arrested for shoplifting and having an automobile accident). All these scenarios produced elevated expectancies for their occurrence among participants who imagined them relative to participants that imagined unrelated activities (e.g. going to the library). These studies also demonstrated that the scenario-expectancy effect occurs for both positive and negative events and for events involving one-self not just others. In distinction to these scenarios prepared beforehand, Anderson (1983) tested the "behavioural scripts" - participants had to sketch out drawings depicting them in performing different activities (e.g. donating blood, taking a new part-time job). Sketching activities served to increase expectancies for the occurrence of those events, repetition of the exercise served to enhance the effect. It was interesting that these expectancies wouldn't have changed if the participants were imagining a friend or a disliked person engaging in the same events. This lead Anderson to conclusion that scenario-expectancy effect occurs only when one-self is depicted in scenario. Sherman (1985), Anderson and Godfrey (1987) found out that scenario-expectancy effect is stronger if the events presented in scenarios are easier to imagine. An experiment included engaging in target behaviours both, before and after picturing themselves in different behaviour, also the ease of the imagining the behaviour was rated. The experiment showed that the easier behaviour was to imagine, the more likely the behaviour became. Some additional studies (Levi and Pryor 1987) supported the role of ease as a mediator of the effect. Moreover, there is a difference in imagining the scenarios if the participants are involved in creation of hypothesis or they are just confronted with them. Koehler (1994) found out that participants had greater confidence if they didn't participate in the creation, yet they were aware that assessing the hypothesis was hard.

Once the scenario influence on expectancies of the occurrence of behaviour was established, researchers Gregory, Cialdini and Carpenter (1982) tried to determine whether scenarios can influence the behaviour itself. They tested the hypothesis that people would increase their compliance once they imagined themselves performing the behaviour. As prior research has shown (Aronson, Carlsmith 1962; Sherman 1980, Weaver, Brickman 1974; Anderson et al. 1980; Sherman et al. 1981), people are reluctant to abandon or disconfirm their expectancies, especially those for which they have imagined an account. This reluctance could directly influence their performing the behaviour: people reluctant to abandon the expectancy might feel compelled to perform a behaviour consistent with it. Also reluctance to abandon an expectancy could indirectly influence the performance of a behaviour trough attitude changes. Gregory, et al. (1982) confirmed that imagined scenarios could influence behaviour. They performed an experiment with residents, to half of whom the scenarios depicting 
having a cable television were presented, other half just gained information about CATV. As a result many more residents from the first group, $47 \%$ compared to $20 \%$ from the second group, actually subscribed to CATV as it became reachable. Scenarios that were used here were prepared in advance, however, Sherman and Anderson (1987) asked the participants to picture themselves in certain activity (getting a therapy) and they have gained similar results. Padilla and Gregory (1997) compared both types of scenarios (expert-generated and selfgenerated) and the results of their experiment suggest that the types of scenarios used may interact with individual differences; some types of scenarios work better for one person than for others. The findings also suggest that researchers may also need to assess the expectancies and attitudes toward events that are not the focal point of the given scenario, because scenarios may have unanticipated and unassessed consequences.

Beside scenario impacts on expectancies of the occurrence of behaviour and behaviour itself, the effects of scenarios on confidence have also been examined. The experiments of Schnaars and Topol (1987) as well as of Kuhn and Sniezek (1996) provide the knowledge that people have greater confidence in their predictions if they have the assurance (trough reading the scenario) that someone else believed in the outcome.

Listed research of scenario influence refers more to the ease with which one constructs the scenarios and their plausibility than to the ease of recalling relevant instances. Also all these examples have no direct connection with environment or landscape or spatial planning however. The research was mainly based on experiments that could be performed in a controlled environment and where credible results could be gathered and evaluated.

The authors of extensive review on scenario influence, Gregory and Duran (2001) conclude that scenarios can be used to enhance the expectancies that an event will occur. Scenarios can also decrease existing expectancies, when they are contradictory to the expectancies. It is then up to practitioners to lead the clients to develop problem-solving strategies for dealing with the problems presented with scenarios. These presented empirical investigations offer the researchers plenty of issues for scientific work and also draw attention to the aspects that should be further investigated, namely the risks of scenario use and the circumstances that might affect the results of scenario use.

\subsection{Land use scenarios}

In landscape planning scenario refers to different possible stories, or alternative assumptions that underline landscape change; the land cover pattern and functional consequences that may be an outcome of the scenario is referred to as "future" (Steinitz et al., 2003). Such scenarios mainly present the future changes of landscape through changes of land use that consequently result also as changes of land cover pattern.

Land use scenarios are actually a planning tool or aid. Consequently, articles about land use scenarios present case studies of their use. No articles focused on psychological effects of land use scenarios were found. Precisely there were no direct results on landscape scenarios impacts on perceptions, changes of values or behaviour that would be scientifically observed and proven. However, some articles presenting scenariobased planning process also include observations of impacts that scenarios had on the participants.

The authors B. Tress and G. Tress (2003) presented the background and the results of a study concerning participatory planning of the Danish countryside. The study combined scenario technique, photorealistic visualization and participation of stakeholders, in order to identify the interests in the future countryside. Four different extreme scenarios for 2020, based on monofunctional land uses, were presented to stakeholders. The participants had to answer a questionnaire asking for comments on each scenario; this was followed by an open discussion about the presentation and participant's fears, wishes and ideas for future development. An interesting observation was that the participants feared that presented scenarios could come true. The researchers had to repeat to them for several times that the results of this study would not be realised. However, apart from influence of clearly vivid scenarios this could be partly attributed to mistrust of the planning and administration authorities.

According to Wollenberg et al. (2000) scenarios enable managers (of the community forests) to understand better the landscape and larger scale forests, improve cooperation with stakeholders at these levels and to improve adaptiveness not only by responding to changes, but also anticipating them. The role of scenarios was here more educational, but there was a very important issue presented that the use of scenarios can help to anticipate changes. Authors used scenarios as a stimulation of adaptive co-management that relies on iterative social learning among stakeholders and the on-going adjustment of management decisions to be acceptable to relevant actors. Scenarios were here used to encourage critical thinking about risks and system relationships, as they provide the focus on the analysis of uncertainties, drivers of change and causal relationships associated with a potential decision. Scenarios introduce hypothetical possibilities that spur people's imagination and enable them to adjust their

Acta agriculturae Slovenica, 93 - 1, maj 2009 
mental habits. The benefit in this case was improved cooperation of stakeholders and facilitated exchange of information; they also influence each stakeholders thinking and actions to enable coordination and improved management. In this experiment stakeholders were treated as actors and were involved in the scenario process. The results have been used for developing land use and forest resource management plans and to provide the basis for residents claims to the use of forest resources located in the national park. In the example of community forestry, scenarios proved to be useful as they broaden the perspectives about how the forests might change in unexpected ways and served as a basis for reaching agreement among different stakeholders. The authors subject that scenarios involving multiple stakeholders can speed up the information exchange and enhance adaptiveness by expanding the availability and flow of information for decision making.

To return back to the European landscape, the case study of Bruns et al. (2000) presents the projection of possible trends of German countryside development. The authors suggest that experiencing landscapes happens in practical projects, and such projects including building and presenting scenarios can help to open the discussion of the future of a particular landscape. By directly involving people as actors of landscape change into analysis, design and planning their knowledge unfolds. The confrontation of different aspects and expectations of the future can finally be realized by the help of professional planners and results in broadly supported plans that are eventually carried out in the real landscape.

Another aspect of scenario use is improving public participation in global environment change assessments and politics. Four different scenarios of energy use represented trough collages were used by Kasemir et al. (2003) in integrated assessment (IA) focus groups in four research regions (Barcelona, Frankfurt, Stockholm and Switzerland). The focus of the study was to develop and apply methods for empirical qualitative studies of public perceptions related to global environmental change. Firstly participants were confronted with current scientific knowledge on climate change with the help of computer models. The study included visual expressions of citizens associations with energy use and its relation to climate change that was followed by the explanation. Participants had to summarize their own views at the end of the process in the form of written citizen reports. They were asked to produce collages on alternative futures using pictures they selected from the magazines provided by the research teams. The collage work was used as a projective technique. Confronted with the unstructured material participants were able to express both hopes and fears trough producing collages. As a concrete task, participants were asked to imagine, how their region might look in thirty years time under two different assumptions: if present trends of the energy use continue (business-as-usual) or if energy use is reduced to half its current level within the next thirty years (strong reduction of energy use). Some of the collages turned out either unambiguously positive or negative, others explicitly showed different types of ambiguity. Collages were than classified according to different positive and negative association categories. Clearly negative collages were only found between business-as-usual scenarios, clearly positive only for energy reduction scenarios. The presentation of collages was accompanied with different emotions; fear, cynicism, black humour, uncertainty, ambiguity and on the other side, positive feelings as hope. Also the regional differences were noticed; different European regions seem to defer in cultural affiliation with regard to complex environmental issues. The project reflected the ability of general public to understand the ambiguities of climate change and a need to bridge the way between experts and lay people considering uncertainties in climate change research to make a more differentiated public debate possible.

The use of scenarios in landscape planning is much broader and as previously mentioned, the use of scenario techniques in landscape planning as well as in other disciplines is gaining popularity. The development of different techniques that enable a vivid presentation of scenarios makes them more and more attractive and convincing. Although only limited number of cases was presented above, they show that the role of land use scenarios is various: scenarios as an aid for learning, discussing, researching and planning. The chosen cases indicate that scenarios actually stimulate the imagination and broaden our knowledge, in this sense they can also influence changes of our perception, expectations about future and also in some cases they can influence our actions and behaviour. 


\section{CONCLUSION}

The review of the literature shows that scenarios are a very diversified and applicable tool. As they can be used in different disciplines and for various purposes also their form and contents vary. The review was carried out to answer the question whether land use scenarios can influence the changes of perceptions and the attitude of the individuals by showing them, how the future landscape will look like.

From a great number of articles dealing with scenarios, articles that present scenarios in the field of landscape planning, articles oriented towards research of psychological influences of scenarios and articles dealing with theory and ethics were examined in this review.

Review indicated a difference between two main purposes of scenario use. Firstly, scenarios as a research tool, used in studies exploring the influence on perception and behaviour of individuals and secondly scenarios as planning tool, aiming at improving communication between different stakeholders, acquiring information from public or individuals, informing about land use and environment changes. As previously mentioned, both ways of scenario use are important for investigating the influence of land use scenarios.

The scenario influence on expectancies and behaviour was clearly demonstrated by scientific experiments, yet, just some of them were indirectly linked with spatial characteristics. There were also many indirect observations and remarks that land use scenarios influence changes of perceptions and behaviour, as they were observed during planning processes. Despite the frequent use of scenarios in landscape planning, the influence of scenarios on perceptions and behaviour of individuals towards landscape is probably difficult to assess or it is not a part of the interest during the planning process. Since there were no articles found, focused on actual psychological influence of land use scenarios, the acquired knowledge on these two aspects of scenario use will have to be combined and widen trough further research. This issue is most important as land use scenarios are often used without sufficient knowledge of their influence on individuals included in planning process and indirectly on landscape and environment.

However the review confirmed that the scenarios permit us to broaden our cognition of events that have not yet occurred. Their vivid form makes it easy to picture environments, persons and other conditions of the future events. By experiencing trough imagination, the scenarios influence our current point of view, depending on our perception abilities, our interest and other personal characteristics.

\section{REFERENCES}

Aligica, P. D., 2005. Scenarios and the growth of knowledge: Notes on the epistemic element in scenario building. Technological Forecasting \& Social Change 72: 815-824.

Bruns, D., Ipsen, D., Bohnet I., 2000. Landscape dynamics in Germany. Landscape and Urban Planning 47: 143-155.

Gregory, W. L., Duran, A., 2001. Scenarios and acceptance of forecasts. Principles of forecasting: A Handbook for Researchers and Practitioners. Ed.: Armstrong, J. S. Kluwer Academic, Boston, MA.: 519-540.

Kasemir, B., Dahinden, U., Swartling, A. G., Schibli, D., Schuele, R., Tabara, D., Jaeger, C. C., 2003. Collage processes and citizens' visions for the future. Public Participation in Sustainability Science; A Handbook. Ed.: Kasemir, B., Jaeger, J., Jaeger, C. C., Gardner, M.T. Cambridge University Press. Cambridge, UK.: 81-104.

Lindgren, M., Bandhold, H., 2003. Scenario planning. The link between future and strategy. Palgrave Macmillan, Hampshire and New York.
Mannermaa, M., 2000. Multidisciplinarity, Methodologies, futures studies. Futures research quarterly, Vol. 16, No. 2, summer 2000: 5-20.

Masini, E. B., Vasquez, J. M., 2000. Scenarios as seen from a human and social perspective. Technological Forecasting and Social Change 65: 49-66.

Principles of Forecasting; A handbook for Researchers and Practitioners, 2001. Ed.: Armstrong, J. S. Springer Science + Business Media Inc., New York, USA.

Public Participation in Sustainability Science; A Handbook, 2003. Ed.: Kasemir, B., Jaeger, J., Jaeger, C. C., Gardner, M.T. Cambridge University Press. Cambridge, UK.

Santelmann, M. V., White, D., Freemark, K., Nassauer, J. I., Eilers, J. M., Vache, K. B., Danielson, B. J., Corry, R. C., Clark, M. E., Polasky S., Cruse R. M., Sifneos, J., Rustigan, H., Coiner, C., Wu, J., Debinski, D., 2004. Assessing alternative futures for agriculture in Iowa, USA. Landscape ecology 19, Kluwer academic Publishers, Netherlands: 357-374. 
Shearer, A., 2005. Approaching scenario based studies: three perceptions about the future and considerations for landscape planning. Environment and planning B: Planning and Design, January 2005, Volume 32, Number 1: $67-87$.

Schwartz, P., 1991. The art of the long view. Doubleday, New York.

Steinitz, C., Arias, H., Bassett, S., Flaxman, M., Goode T., Maddock III T., Mouat D., Preiser R., Shearer, A., 2003. Alternative Futures for Changing Landscapes: The upper San Pedro River Basin in Arizona and Sonora. Island Press, Washington, DC, USA.
Wollenberg, E., Edmunds, D., Buck, L., 2000. Using scenarios to make decisions about the future: anticipatory learning for the adaptive co-management of community forests. Landscape and Urban Planning 47: 65-77.

Tress, B., Tress, G., 2003. Scenario visualization for participatory landscape planning - a study from Denmark. Landscape and Urban Planning 64: 161-178.

Wikipedia-the free encyclopedia, http://en.wikipedia.org, 2007-08-01 227. 